\title{
HUBUNGAN ANTARA FAKTOR INDIVIDU DAN KEJENUHAN DENGAN STRES KERJA PADA GURU SEKOLAH DASAR SEDERAJAT
}

\section{RELATIONSHIP BETWEEN INDIVIDUAL FACTORS AND BOREDOM WITH JOB STRESS ON ELEMENTARY SCHOOL TEACHERS AND EQUIVALENT}

\author{
Siti Farihah Rosanna*, Ragil Ismi Hartanti, Reny Indrayani \\ Program Studi Ilmu Kesehatan Masyarakat, Fakultas Kesehatan Masyarakat, Universitas Jember, \\ Jl. Kalimantan No.I/93 68121 Jember, Jawa Timur, Indonesia \\ *email: ocha80132@gmail.com
}

\begin{abstract}
Boredom is one of the causes of job stress. One of the risky jobs for work stress is elementary school teacher because they have a greater responsibility and monotone work routine. Job stress is caused by individual factors which include gender, age and work period as well as boredom, so prevention efforts need to be made. The purpose of this research was to analyze the correlation between individual factors and boredom with job stress on elementary school teachers and equivalent at Wuluhan District, Jember Regency. This research was an analytic study and used a cross-sectional research design. The population in this research was active teachers with a total of 535 while the samples were 116 teachers. The data used in this research was primary data obtained through online questionnaires using google form. The instrument used Boredom Proneness Scale (BPS) to determine boredom and the Occupational Stress Inventory-Revised (OSI-R) to determine job stress. Bivariate data analysis was carried out using the Chi-Square with a significance value $(\alpha)=0,05$. The results showed that gender ( $p$-value $=0,585)$ and work period ( $p$-value $=0.203$ ) haven't correlation with job stress. Age $(p$-value $=0.049)$ have a significant correlation with job stress and haven't correlation between boredom ( $p$-value $=0.602)$ with job stress. Based on results, the conclusion is that there were respondents who experienced high levels of boredom and job stress. Suggestions that can be given to school principals were to conduct evaluations to known obstacles perceived by the teacher and conduct training to support their competencies.
\end{abstract}

Keyword: job stress, boredom, individual factors, elementary school teachers and equivalent

\begin{abstract}
Abstrak
Kejenuhan merupakan salah satu penyebab terjadinya stres kerja. Salah satu pekerjaan yang berisiko mengalami stres kerja adalah guru Sekolah Dasar Sederajat karena memiliki tanggungjawab yang lebih besar dan rutinitas kerja monoton. Stres kerja disebabkan oleh faktor individu yang meliputi jenis kelamin, usia dan masa kerja serta kejenuhan sehingga perlu dilakukan upaya pencegahan. Tujuan dari penelitian ini adalah untuk menganalisis hubungan antara faktor individu dan kejenuhan dengan stres kerja pada guru Sekolah Dasar Sederajat di Kecamatan Wuluhan, Kabupaten Jember. Penelitian ini merupakan penelitian analitik dengan desain cross-sectional. Populasi pada penelitian ini sebanyak 339 guru dengan sampel sebanyak 116 guru. Data yang digunakan dalam penelitian ini merupakan data primer yang didapatkan melalui angket online dengan menggunakan google form. Instrumen penelitian menggunakan Boredom Proneness Scale (BPS) untuk mengetahui kejenuhan dan Occupational Stress Inventory Revised (OSI-R) untuk mengetahui stres kerja. Analisis data bivariat dilakukan dengan menggunakan uji Chi-Square. Hasil penelitian menunjukkan bahwa jenis kelamin $(p$-value $=0,585)$ dan masa kerja ( $p$-value $=0,203)$ tidak memiliki hubungan dengan stres kerja. Terdapat hubungan antara usia $(p$-value $=0,049)$ dengan stres kerja dan tidak terdapat hubungan antara
\end{abstract}


kejenuhan $(p$-value $=0,602)$ dengan stres kerja. Berdasarkan hasil penelitian, diperoleh kesimpulan bahwa terdapat responden yang mengalami kejenuhan dan stres kerja berat. Saran yang dapat diberikan kepada kepala sekolah adalah untuk melakukan evaluasi berupa sharing terkait hambatan yang dirasakan guru dan melakukan pelatihan untuk menunjang kompetensi yang dimiliki.

Kata Kunci: stres kerja, kejenuhan, faktor individu, guru sekolah dasar sederajat

\section{PENDAHULUAN}

Stres kerja merupakan kondisi dari hasil ketidaksesuaian kapasitas, sumber daya, dan kebutuhan pekerja sehingga menyebabkan gangguan secara psikologis, fisiologis, dan perilaku (Muhbar dan Rochmawati, 2017). Data Labour Force Survey pada tahun 2018/2019 menunjukkan bahwa terdapat 602.000 kasus stres kerja di Inggris (Health and Safety Executive, 2019). Europan Opinion Poll on Occupational Safety and Health juga mengeluarkan data pekerja yang menyatakan mengalami stres kerja di tempat kerja yaitu sebanyak 51\% (EU-OSHA, 2013).

Menurut Farista (2018), salah satu pekerja yang berisiko mengalami stres kerja adalah guru Sekolah Dasar Sederajat karena memiliki rutinitas pekerjaan monoton. Penelitian yang dilakukan oleh Pertiwi dan Wardani (2019) menunjukkan bahwa guru Sekolah Dasar mengalami stres kerja sedang sebesar $81,5 \%$ karena guru berinteraksi lebih lama dengan siswa sehingga perilaku dan permasalahan siswa menjadi tanggung jawab guru. Peran guru tidak hanya sebatas membuat rancangan pembelajaran, mengajar, dan memeriksa tugas siswa, namun juga bertanggung jawab terhadap tingkat prestasi akademik siswa (Heriyansyah, 2018). Guru kelas merupakan penentu kualitas pembelajaran sehingga rentan mengalami stres kerja (Akbar dan Pratasiwi, 2017). Salah satu faktor yang mempengaruhi stres kerja adalah kejenuhan sebesar 30,6\% (Putranto, 2013).

Kejenuhan adalah kondisi tidak menyenangkan akibat tuntutan yang membebankan atau melebihi kapasitas individu (Susanti et al., 2018). Kejenuhan terjadi karena rutinitas pekerjaan monoton sehingga terjadi penurunan produktivitas, peningkatan absensi, dan stres kerja (Susanti et al., 2018). Kejenuhan sering dijumpai pada pekerja di bidang pelayanan kemanusiaan seperti perawat (43\%), guru $(32 \%)$, polisi $(4 \%)$, dan pada pekerja lain (2\%) (Wardhani et al., 2020). Kejenuhan pada guru Sekolah Dasar Sederajat salah satunya diakibatkan oleh metode pembelajaran yang digunakan monoton (metode ceramah) (Zetli,
2019). Metode ceramah memiliki kekurangan, yaitu menjadikan siswa pasif sehingga memicu guru mengalami kejenuhan karena pembelajaran kurang interaktif dan kurang mendapatkan tantangan dari pekerjaan yang dilakukan (Muslicha, 2015).

Penyebab lain stres kerja yaitu faktor individu (jenis kelamin, usia, dan masa kerja). Pekerja perempuan cenderung mendahulukan perasaan dan mengalami siklus haid sehingga mempengaruhi emosionalnya (Amalia et al., 2017). Semakin bertambah usia, maka terjadi penurunan kemampuan berpikir, mengingat, dan kondisi kesehatan yang terganggu (Sumarna et al., 2018). Masa kerja berhubungan dengan pengalaman kerja seseorang. Pekerja yang mempunyai masa kerja lama cenderung telah memahami alur tugas yang dilakukan sehingga lebih mudah mengelola tekanan kerja sehingga stres kerja juga akan menurun (Manabung et al., 2018).

Stres kerja pada guru ditunjukkan dengan perasaan gelisah sehingga kurang fokus saat mengajar (Hendrawan et al., 2018). Penurunan konsentrasi pada guru akan berpengaruh terhadap tidak maksimalnya kualitas dan kuantitas pembelajaran yang dilakukan. Guru juga mengalami kehilangan kontrol menghadapi siswa dan tuntutan pekerjaan sehingga mudah marah. Penurunan kinerja guru menyebabkan penurunan prestasi siswa (Harmsen et al., 2018). Stres kerja guru mengakibatkan hubungan siswa dengan guru menjadi kurang baik sehingga menghambat pencapaian mutu pendidikan (Suparman, 2018).

Salah satu wilayah dengan jumlah Sekolah Dasar Sederajat yang besar adalah Kabupaten Jember dengan jumlah Sekolah Dasar Sederajat tertinggi berada di Kecamatan Wuluhan yaitu sebanyak 76 SD/MI. Berdasarkan hasil studi pendahuluan, diketahui bahwa $13,89 \%$ guru terindikasi mengalami stres kerja rendah, 63,89\% stres kerja sedang, dan $22,22 \%$ stres kerja tinggi. Penelitian ini bertujuan untuk mengetahui hubungan antara faktor individu dan kejenuhan dengan stres kerja pada Guru Sekolah Dasar Sederajat di Kecamatan Wuluhan, Kabupaten Jember. 


\section{METODE PENELITIAN}

Penelitian ini menggunakan pendekatan kuantitatif dengan jenis penelitian analitik dan desain cross-sectional. Penelitian dilaksanakan pada Januari 2021 di 48 Sekolah Dasar Sederajat di Kecamatan Wuluhan, Kabupaten Jember. Populasi penelitian sebanyak 339 responden dengan sampel penelitian sebanyak 116 responden. Teknik pengambilan sampel menggunakan metode proportional random sampling dan simple random sampling.

Proportional random sampling merupakan teknik sampling dengan menghasilkan perbandingan jumlah sampel yang seimbang antara besar sampel dan populasi pada tiap subkelompok yang kemudian diambil secara acak (Yusuf, 2014). Hal ini dikarenakan populasi penelitian terdiri dari 48 sekolah di wilayah Kecamatan Wuluhan dengan lokasi dan jumlah guru yang berbeda setiap sekolah. Teknik pengambilan sampel selanjutnya adalah menggunakan simple random sampling yaitu setelah diperoleh jumlah sampel pada masing-masing sekolah, dilakukan pengambilan secara acak pada masing-masing sekolah tersebut dengan menggunakan undian.

Variabel pada penelitian ini meliputi variabel bebas yaitu faktor individu (jenis kelamin, usia, dan masa kerja) dan kejenuhan dengan variabel terikat yaitu stres kerja. Data faktor individu, kejenuhan, dan stres kerja merupakan data primer yang dikumpulkan melalui angket online menggunakan google form. Instrumen dalam penelitian ini menggunakan Boredom Proneness Scale (BPS) untuk mengetahui kejenuhan dan Occupational Stress Inventory Revised (OSI-R) untuk mengetahui stres kerja. Instrumen baku ini terdiri dari 28 pertanyaan dengan rincian 18 pertanyaan positif dan 10 pertanyaan negatif. Setiap pertanyaan terdiri dari 7 skala jawaban dengan skor total diklasifikasikan menjadi Tingkat Kejenuhan Ringan (28-80) dan Tingkat Kejenuhan Berat (81-196).

Instrumen untuk menilai tingkat stres kerja responden menggunakan angket online Occupational Stress Inventory Revised yang dikembangkan oleh Osipow dan Spokane (1998) yang terdiri dari 25 pertanyaan. Setiap pertanyaan terdiri dari 5 skala jawaban dengan skor total diklasifikasikan menjadi Tingkat Stres Ringan (25-92) dan Tingkat Stres Berat (93-125). Analisis data secara bivariat menggunakan uji Chi-Square dengan nilai signifikansi 0,05 .

\section{HASIL DAN PEMBAHASAN}

\section{Distribusi Frekuensi Faktor Individu, Kejenuhan, dan Stres Kerja}

Hasil pengumpulan data terkait faktor individu, kejenuhan, dan stres kerja pada guru Sekolah Dasar Sederajat di Kecamatan Wuluhan, Kabupaten Jember ditampilkan pada Tabel 1.

Tabel 1. Distribusi Frekuensi Faktor Individu, Kejenuhan, dan Stres Kerja pada Guru Sekolah Dasar Sederajat di Kecamatan Wuluhan, Kabupaten Jember

\begin{tabular}{lrr}
\hline Faktor Individu & Jumlah & \multicolumn{2}{c}{ Persentase (\%) } \\
\hline Jenis Kelamin & & \\
Laki-laki & 41 & 35,3 \\
Perempuan & 75 & 64,7 \\
Usia & & \\
$\leq 35$ tahun & 41 & 35,3 \\
$>35$ tahun & 75 & 64,7 \\
Masa Kerja & & \\
$\leq 5$ tahun & 24 & 20,7 \\
$>5$ tahun & 92 & 79,3 \\
Kejenuhan & & \\
Ringan & 17 & 14,7 \\
Berat & 99 & 85,3 \\
Stres Kerja & & \\
Ringan & 108 & 93,1 \\
Berat & 8 & 6,9 \\
\hline Total & $\mathbf{1 1 6}$ & $\mathbf{1 0 0 , 0}$ \\
\hline
\end{tabular}

\section{a. Faktor Individu}

Data pada Tabel 1 menunjukkan sebagian besar guru berjenis kelamin perempuan, yaitu sebanyak 75 responden dengan persentase $64,7 \%$. Usia responden lebih banyak terdapat pada kelompok usia > 35 tahun, yaitu sebanyak 75 responden dengan persentase $64,7 \%$. Sebagian besar responden memiliki masa kerja $>5$ tahun, yaitu sebanyak 92 responden dengan persentase 79,3\%.

Pada faktor jenis kelamin, terdapat perbedaan kondisi fisiologis antara laki-laki dan perempuan menyebabkan perbedaan terjadinya stres kerja. Menurut Amalia et al. (2017), perempuan cenderung mendahulukan perasaan dan mengalami siklus menstruasi sehingga berpengaruh pada kondisi emosionalnya. Kondisi emosional yang tidak stabil menyebabkan perempuan kehilangan kontrol emosi sehingga mudah marah. Hasil penelitian yang dilakukan pada guru Sekolah Dasar Sederajat di Kecamatan Wuluhan, Kabupaten 
Jember diketahui bahwa sebagian besar guru berjenis kelamin perempuan. Hal tersebut dikarenakan pekerjaan menjadi guru memerlukan kesabaran dan kreativitas (Perwiraningsih dan Hidayat, 2020). Guru perlu memiliki kreativitas karena siswa Sekolah Dasar Sederajat berada pada tahap awal untuk menempuh pendidikan. Selain bekerja, guru perempuan juga memiliki tanggung jawab untuk melakukan pekerjaan rumah. Perempuan juga mengalami siklus menstruasi sehingga dengan beban kerja tinggi dan kondisi emosional yang tidak stabil tersebut menyebabkan perempuan lebih rentan mengalami stres kerja daripada laki-laki (Ansori dan Martiana, 2017).

Pada faktor usia, usia berhubungan dengan kapasitas fisik dan kemampuan yang dimiliki pekerja. Semakin bertambah usia, maka terjadi penurunan kondisi fisik seperti kemampuan berpikir, mengingat, dan kondisi kesehatan yang semakin terganggu (Sumarna et al., 2018). Hal tersebut menunjukkan semakin bertambah usia, maka terjadi penurunan kemampuan sehingga menyebabkan stres kerja. Hasil penelitian yang dilakukan pada guru Sekolah Dasar Sederajat di Kecamatan Wuluhan, Kabupaten Jember diketahui bahwa lebih banyak guru berada pada rentang usia 2635 tahun, yaitu masuk kategori masa dewasa awal. Pekerja yang berada pada masa dewasa mempunyai kemampuan mengontrol diri termasuk emosionalnya, sehingga manajemen stres yang dilakukan lebih baik daripada remaja dan lansia (Perwiraningsih dan Hidayat, 2020). Usia berhubungan dengan tingkat toleransi terhadap penyebab stres kerja. Semakin bertambah usia, maka terjadi penurunan kemampuan fisik seperti kemampuan berpikir sehingga menyebabkan pekerja merasa bekerja di bawah tekanan dan melebihi kapasitas yang dimiliki (Zulkifli dan Sulung, 2019). Pada usia lansia juga terjadi penurunan kemampuan seperti penglihatan, pendengaran, dan persendian. Seiring penurunan fungsi fisiologis tersebut, imunitas juga menurun sehingga rentan mengalami gangguan kesehatan (Kaunang et al., 2019).

Masa kerja berhubungan dengan pengalaman kerja seseorang. Pekerja yang memiliki masa kerja lama cenderung memahami alur tugas yang diberikan sehingga dapat mengelola tekanan kerja dan telah mampu beradaptasi dengan lingkungan kerja (Manabung et. al., 2018). Kemampuan beradaptasi merupakan salah satu kunci untuk menciptakan kenyamanan bekerja sehingga dapat mencegah terjadinya stres kerja (Perwiraningsih dan Hidayat, 2020). Hasil penelitian yang dilakukan pada guru Sekolah Dasar Sederajat di Kecamatan Wuluhan, Kabupaten Jember diketahui bahwa sebagian besar guru berada pada rentang masa kerja sedang yaitu 5-20 tahun. Menurut Zulkifli dan Sulung (2019), terdapat dampak positif dan negatif terkait masa kerja lama yang dimiliki oleh pekerja. Semakin lama masa kerja, maka berhubungan dengan peningkatan pemahaman alur pekerjaan yang dilakukan. Pengalaman tersebut dapat digunakan untuk membantu dalam menyelesaikan masalah atau penyebab stres kerja di tempat kerja, namun sebaliknya, masa kerja juga dapat menyebabkan timbulnya kejenuhan kerja jika rutinitas yang dilakukan monoton, pekerjaan yang dilakukan tidak menarik, dan lingkungan kerja yang tidak mendukung sehingga memicu terjadinya stres kerja.

\section{b. Kejenuhan}

Data pada Tabel 1 menunjukkan sebagian besar responden mengalami kejenuhan berat, yaitu sebanyak 99 responden dengan persentase $85,3 \%$. Kejenuhan berat merupakan kondisi keberlanjutan akibat kejenuhan yang dirasakan ketika bekerja. Jika pekerja tidak berhasil melakukan perlawanan, maka kejenuhan akan berlangsung terus-menerus sehingga menimbulkan dampak merugikan bagi guru seperti terjadinya stres kerja.

Guru yang telah mengalami kejenuhan dalam melakukan pembelajaran karena terlalu lama dilakukan dan terus-menerus, maka akan terjadi penurunan semangat kerja. Tidak semua guru dapat bertahan dengan jenis pekerjaan yang berulang-ulang atau pada pekerjaan yang sama. Pekerja yang merasakan kejenuhan dengan pekerjaannya akan lebih mudah marah, sulit berkonsentrasi dan penurunan kinerja (Suparman, 2017).

\section{c. Stres Kerja}

Data pada Tabel 1 menunjukkan paling banyak responden mengalami stres kerja ringan, yaitu sebanyak 108 responden $(93,1 \%)$. Selain itu, pada Tabel 1 juga didapatkan informasi bahwa terdapat responden yang mengalami stres kerja berat yaitu sebanyak 8 responden dengan persentase $6,9 \%$. Hal ini disebabkan karena selain bertugas menyampaikan 
pembelajaran kepada siswa, guru kelas juga berperan dalam melatih kepribadian, mental, dan perilaku siswa, karena siswa Sekolah Dasar Sederajat masih berada dalam tahap awal untuk membentuk konsep pemahaman (Wibowo dan Maqfirotun, 2016). Guru juga perlu mempunyai kemampuan dalam penguasaan dan penerapan berbagai macam metode pembelajaran untuk mencapai hasil pembelajaran yang maksimal (Nasution, 2017). Guru perlu mengembangkan keahlian baru seperti mengikuti pelatihan pengembangan kompetensi sehingga metode pembelajaran sesuai, inovatif, dan lebih mudah dipahami siswa (Shabir, 2015).

\section{Hubungan antara Faktor Individu dan Kejenuhan dengan Stres Kerja}

Hasil analisis hubungan antara faktor individu dan kejenuhan dengan stres kerja pada guru Sekolah Dasar Sederajat di Kecamatan Wuluhan, Kabupaten Jember ditampilkan pada Tabel 2 sebagai berikut:

Tabel 2. Hubungan antara Faktor Individu dan Kejenuhan dengan Stres kerja pada Guru Sekolah Dasar Sederajat di Kecamatan Wuluhan, Kabupaten Jember

\begin{tabular}{|c|c|c|c|c|c|c|c|}
\hline \multirow{3}{*}{$\begin{array}{l}\text { Faktor Individu } \\
\text { dan Kejenuhan }\end{array}$} & \multicolumn{4}{|c|}{ Stres Kerja } & \multirow{2}{*}{\multicolumn{2}{|c|}{ Total }} & \multirow{3}{*}{$\begin{array}{c}p- \\
\text { value }\end{array}$} \\
\hline & \multicolumn{2}{|c|}{ Ringan } & \multicolumn{2}{|c|}{ Berat } & & & \\
\hline & $\mathbf{N}$ & $\%$ & $\mathbf{N}$ & $\%$ & $\mathbf{N}$ & $\%$ & \\
\hline \multicolumn{8}{|l|}{ Jenis Kelamin } \\
\hline Laki-laki & 38 & 32,8 & 3 & 2,6 & 41 & 35,3 & \multirow{2}{*}{0,585} \\
\hline Perempuan & 70 & 60,3 & 5 & 4,3 & 75 & 64,7 & \\
\hline \multicolumn{8}{|l|}{ Usia } \\
\hline$<=35$ tahun & 41 & 35,3 & 0 & 0,0 & 41 & 35,3 & \multirow{2}{*}{0,049} \\
\hline$>35$ tahun & 67 & 57,8 & 8 & 6,9 & 75 & 64,7 & \\
\hline \multicolumn{8}{|l|}{ Masa Kerja } \\
\hline$<=5$ tahun & 24 & 20,7 & 0 & 0,0 & 24 & 20,7 & \multirow{2}{*}{0,203} \\
\hline$>5$ tahun & 84 & 72,4 & 8 & 6,9 & 92 & 79,3 & \\
\hline \multicolumn{8}{|l|}{ Kejenuhan } \\
\hline Ringan & 17 & 14,7 & 0 & 0,0 & 17 & 14,7 & \multirow{2}{*}{0,602} \\
\hline Berat & 91 & 78,4 & 8 & 6,9 & 99 & 85,3 & \\
\hline Total & 108 & 93,1 & 8 & 6,9 & 116 & 100,0 & \\
\hline
\end{tabular}

\section{Hubungan antara Faktor Individu dengan} Stres Kerja

\section{a. Hubungan antara Jenis Kelamin dengan Stres Kerja}

Data yang disajikan dalam Tabel 2 menunjukkan bahwa paling banyak responden mengalami stres kerja ringan yaitu sebanyak sebanyak 108 responden yang terdiri dari 38 responden laki-laki dan 70 responden perempuan. Hasil penelitian tersebut menunjukkan bahwa terdapat juga responden yang mengalami stres kerja berat, yaitu sebanyak 8 responden yang terdiri dari 3 responden laki-laki dan 5 responden perempuan. Berdasarkan hasil analisis bivariat menggunakan uji Chi-Square dengan $\alpha=0,05$, diperoleh hasil $\mathrm{p}>\alpha$, yaitu $0,585>0,05$. Hal tersebut menunjukkan bahwa $\mathrm{H}_{0}$ diterima yang artinya tidak terdapat hubungan antara jenis kelamin dengan stres kerja pada guru Sekolah
Dasar Sederajat di Kecamatan Wuluhan, Kabupaten Jember. Penelitian ini sejalan dengan penelitian Wahdaniyah dan Miftahuddin (2018) yang menyatakan bahwa tidak terdapat hubungan antara jenis kelamin dengan stres kerja. Hasil penelitian ini tidak sesuai dengan teori Sumarna et al. (2018) yang menyatakan bahwa perempuan mendahulukan perasaan dan mengalami siklus haid sehingga akan mempengaruhi kondisi emosionalnya.

Tidak sejalannya penelitian ini dengan teori dapat diartikan bahwa antara guru laki-laki maupun perempuan tidak memiliki perbedaan, keduanya memiliki peluang yang sama untuk mengalami stres kerja. Guru perempuan di Sekolah Dasar Sederajat Kecamatan Wuluhan, Kabupaten Jember memiliki kegiatan rutin untuk menghilangkan penat, seperti berlibur, makan bersama, senam, dan arisan darma wanita. Pertemuan tersebut digunakan untuk saling bercerita terkait permasalahan sehingga 
dapat memperbaiki kondisi psikologis akibat stres kerja yang dirasakan. Hal tersebut yang menyebabkan terjadinya perbedaan antara teori dengan penelitian ini karena walaupun guru perempuan memiliki risiko stres kerja yang lebih tinggi, namun manajemen stres yang dilakukan juga baik.

\section{b. Hubungan antara Usia dengan Stres Kerja}

Data yang disajikan dalam Tabel 2 menunjukkan bahwa paling banyak responden mengalami stres kerja ringan yaitu sebanyak sebanyak 108 responden yang terdiri dari 41 responden berusia $\leq 35$ tahun dan 67 responden berusia $>35$ tahun. Hasil penelitian tersebut menunjukkan bahwa terdapat juga responden yang mengalami stres kerja berat, yaitu sebanyak 8 responden berusia $>35$ tahun. Berdasarkan hasil analisis bivariat menggunakan uji Chi-Square dengan $\alpha=0,05$, diperoleh nilai signifikansi atau $p$-value sebesar 0,049 . Hasil tersebut menunjukkan $p$-value $<\alpha$, yaitu $0,049<0,05$ sehingga $\mathrm{H}_{0}$ ditolak yang artinya terdapat hubungan yang signifikan antara usia dengan stres kerja pada guru Sekolah Dasar Sederajat di Kecamatan Wuluhan, Kabupaten Jember. Penelitian ini tidak sejalan dengan penelitian Amalia et al. (2017) yang menyatakan bahwa tidak terdapat hubungan antara usia dengan stres kerja.

Hasil penelitian ini sesuai dengan teori Sumarna et al. (2018) yang menyatakan bahwa semakin bertambah usia, maka tingkat stres kerja juga bertambah karena telah terjadi penurunan kondisi fisik, seperti kemampuan berpikir, mengingat, dan kondisi kesehatan yang semakin terganggu. Sejalannya penelitian ini dengan teori dapat disebabkan karena guru yang berusia tua telah mengalami penurunan kemampuan yang dimiliki. Ketidaksesuaian antara kapasitas dengan beban kerja dapat menyebabkan peningkatan stres kerja pada guru. Semakin bertambahnya usia guru, maka kemampuan untuk merespon atau melakukan toleransi terhadap stresor mengalami penurunan sehingga dapat menyebabkan stres kerja (Perwiraningsih dan Hidayat, 2020).

\section{c. Hubungan antara Masa Kerja dengan Stres Kerja}

Data yang disajikan dalam Tabel 2 menunjukkan bahwa paling banyak responden mengalami stres kerja ringan yaitu sebanyak sebanyak 108 responden yang terdiri dari 24 responden dengan masa kerja $\leq 5$ tahun dan 84 responden dengan masa kerja $>5$ tahun. Hasil penelitian tersebut menunjukkan bahwa terdapat juga responden yang mengalami stres kerja berat, yaitu sebanyak 8 responden dengan masa kerja $>5$ tahun. Berdasarkan hasil analisis bivariat menggunakan uji Chi-Square dengan $\alpha$ $=0,05$, diperoleh nilai signifikansi atau $p$-value sebesar 0,203. Hasil tersebut menunjukkan $p>$ $\alpha$, yaitu $0,203>0,05$ sehingga $\mathrm{H}_{0}$ diterima yang artinya tidak terdapat hubungan antara masa kerja dengan stres kerja pada guru Sekolah Dasar Sederajat di Kecamatan Wuluhan, Kabupaten Jember. Penelitian ini tidak sejalan dengan penelitian Zulkifli et al. (2019) yang menyatakan bahwa terdapat hubungan antara masa kerja dengan stres kerja.

Hasil penelitian ini tidak sesuai dengan teori Sumarna et al. (2018) yang menyatakan bahwa semakin lama masa kerja, maka pengalaman kerja juga semakin banyak. Pengalaman tersebut dapat membantu mengatasi penyebab stres kerja dibandingkan masa kerja baru yang perlu menyesuaikan diri dengan lingkungan kerja. Tidak sejalannya penelitian ini dengan teori dapat diartikan bahwa pada semua kategori masa kerja tidak terdapat perbedaan tertentu dan memiliki peluang yang sama untuk mengalami stres kerja. Guru telah memiliki kompetensi dan kemampuan untuk menyampaikan pembelajaran kepada siswa sehingga walaupun guru perlu adaptasi di lingkungan kerja baru, namun dengan kemampuan yang dimiliki guru dapat meminimalisir stresor yang terjadi.

\section{Hubungan antara Kejenuhan dengan Stres Kerja}

Data yang disajikan dalam Tabel 2 menunjukkan stres kerja berat lebih banyak dialami oleh responden yang memiliki kejenuhan berat, yaitu sebanyak 8 responden dengan persentase 6,9\%. Berdasarkan hasil analisis bivariat menggunakan uji Chi-Square dengan $\alpha=0,05$, diperoleh nilai signifikansi atau $p$-value sebesar 0,602. Hasil tersebut menunjukkan $\mathrm{p}>\alpha$, yaitu $0,602>0,05$ sehingga dapat disimpulkan bahwa tidak terdapat hubungan antara kejenuhan dengan stres kerja pada guru Sekolah Dasar Sederajat di Kecamatan Wuluhan, Kabupaten Jember. Penelitian ini tidak sejalan dengan penelitian Jundillah et al. (2017) yang menyatakan bahwa terdapat hubungan antara kejenuhan dengan stres kerja. 
Penelitian ini tidak sesuai dengan teori Susanti et al. (2018) yang menyatakan bahwa kejenuhan pada pekerja berhubungan dengan terjadinya stres kerja. Pekerja yang merasa jenuh dengan pekerjaannnya dapat memicu timbulnya ketegangan, cepat marah, sulit konsentrasi maupun sulit bekerja secara efektif. Tidak sejalannya penelitian ini dengan teori dapat disebabkan karena adanya kecanggihan teknologi yang dapat digunakan oleh guru untuk referensi dalam menentukan metode pembelajaran yang sesuai dengan karakteristik siswa. Inovasi pembelajaran yang dilakukan dapat mencegah terjadinya kejenuhan pada guru karena pembelajaran tidak monoton (Dimyati, 2019)

\section{KESIMPULAN DAN SARAN}

\section{Kesimpulan}

Berdasarkan hasil dan pembahasan penelitian, dapat ditarik kesimpulan bahwa pada faktor individu, sebagian besar responden berjenis kelamin perempuan, dengan usia lebih banyak pada kelompok >35 tahun. Masa kerja responden sebagian besar berada pada kategori $>5$ tahun. Sebagian besar responden mengalami kejenuhan berat. Responden paling banyak mengalami stres kerja ringan, namun terdapat beberapa responden yang mengalami stres kerja berat. Pada faktor individu (jenis kelamin dan masa kerja) tidak memiliki hubungan yang signifikan dengan stres kerja, namun pada variabel usia memiliki hubungan dengan stres kerja. Kejenuhan tidak memiliki hubungan yang signifikan dengan stres kerja pada guru Sekolah Dasar Sederajat di Kecamatan Wuluhan, Kabupaten Jember.

\section{Saran}

Saran yang dapat diberikan kepada kapala sekolah yaitu melakukan evaluasi pada kinerja guru, misalnya setiap akhir bulan dilakukan pertemuan untuk sharing terkait keluhan dan hambatan yang dirasakan guru sehingga dapat diperoleh solusi dalam upaya pemecahan masalah secara bersama-sama. Selain itu juga perlu dilakukan pelatihan untuk terus menunjang kompetensi yang dimiliki sehingga ilmu yang dimiliki terus berkembang.

\section{DAFTAR RUJUKAN}

1] Akbar $Z$ and Pratasiwi R (2017) Resiliensi Diri dan Stres Kerja pada Guru Sekolah
Dasar. Jurnal Penelitian dan Pengukuran Psikologi 6(No. 2): 107-112.

2] Amalia B, Wahyuni I and Ekawati (2017) Hubungan antara Karakteristik Individu, Beban Kerja Mental, Pengembangan Karir, dan Hubungan Interpersonal dengan Stres Kerja pada Guru di SLB Negeri Semarang. Jurnal Kesehatan Masyarakat 5(No. 5): 68-78.

3] Ansori R and Martiana T (2017) Hubungan Faktor Karakteristik Individu dan Kondisi Pekerjaan terhadap Stres Kerja pada Perawat Gigi. The Indonesian Journal of Public Health 12(No. 1): 75-84.

4] Dinas Kesehatan Jawa Timur (2020) Profil Kesehatan Provinsi Jawa Timur. Surabaya: Dinas Kesehatan Jawa Timur.

5] Dimyati A (2019) Tingkat Kejenuhan Guru dalam Mengajar Pendidikan Jasmani pada Anak Berkebutuhan Khusus di SMP Luar Biasa di Kabupaten Karawang. Jurnal Ilmiah Penjas 5(No. 2): 37-47.

6] EU-OSHA (2013) European Opinion Poll on Occupational Safety and Health. Bilbao: European Agency for Safety and Health at Work.

7] Farista $D$ (2018) Strategi Pengelolaan Stres Guru Wanita Berstatus Guru Tetap Yayasan Sekolah Dasar Bersistem Full Day School. Jurnal Kajian Teori dan Praktik Kependidikan 3(No. 1): 31-39.

8] Harmsen R, Helms-Lorenz M, Maulana R and Veen K (2018) The Relationship between Beginning Teachers' Stress Causes, Stress Responses, Teaching Behaviour and Attrition. Teachers and Teaching: Theory and Practice 24(No. 6): 626-643.

9] Health and Safety Executive (2019) Workrelated Stress, Anxiety or Depression Statistics in Great Britain. United Kingdom: National Statistics.

10] Hendrawan A, Sucahyawati H, Cahyandi $\mathrm{K}$ and Indriyani (2018) Stres Kerja dan Kelelahan Kerja Pengaruhnya Terhadap Kinerja Guru Sekolah Dasar. Jurnal Ekonomi Manajemen Akuntansi 3(No. 1): 1-13.

11] Heriyansyah (2018) Guru adalah Manajer Sesungguhnya di Sekolah. Jurnal Manajemen Pendidikan Islam 1(No. 1): 116-127. 
12] Jundillah Z, Ahmad L and Saktiansyah L (2017) Analisis Kejadian Stres Kerja pada Perawat di Kabupaten Konawe Kepulauan Tahun 2017. Jurnal Ilmiah Mahasiswa Kesehatan Masyarakat 2(No. 6): 1-11.

13] Kaunang V, Buanasari A and Kallo V (2019) Gambaran Tingkat Stres pada Lansia. Jurnal Keperawatan 7(No. 2): 1-7.

14] Manabung A, South L and Warouw F (2018) Hubungan antara Masa Kerja dan Beban Kerja dengan Stres Kerja pada Tenaga Kerja di PT. Pertamina TBBM Bitung. Jurnal Kesehatan Masyarakat 7(No. 5): 1-10.

15] Muhbar F, dan Dwi H (2017) Hubungan antara Tingkat Stres dengan Beban Kerja Guru di Sekolah Luar Biasa. Jurnal Keperawatan 5(No. 2): 82-86.

16] Muslicha A (2015) Metode Pembelajaran dalam Pendidikan Lingkungan Hidup pada Siswa Sekolah Dasar (Studi pada Sekolah Adiwiyata di DKI Jakarta). Jurnal Pendidikan 16(No. 2): 110-126.

17] Nasution M (2017) Penggunaan Metode Pembelajaran dalam Peningkatan Hasil Belajar Siswa. Jurnal Ilmiah Bidang Pendidikan 11(No. 1): 9-16.

18] Pajow C, Kawatu P and Rattu J (2020) Hubungan antara Beban Kerja, Masa Kerja dan Kejenuhan Kerja dengan Stres Kerja pada Tenaga Kerja Area Opening Sheller PT. Sasa Inti Kecamatan Tenga Kabupaten Minahasa Selatan. Jurnal KESMAS 9(No. 7):28-36.

19] Pertiwi $N$ and Wardani I (2019) Tingkat Stres Kerja dan Strategi Koping Guru SD dalam Implementasi Kurikulum 2013. Jurnal Ilmiah Permas: Jurnal Ilmiah STIKES Kendal 9(No. 2): 155-164.

20] Perwiraningsih J and Hidayat S (2020) Gambaran Risiko Stres Kerja pada Guru Kelas 6 SD Negeri se-Kecamatan Banyuwangi. Majalah Kesehatan Masyarakat Aceh 3(No. 1): 61-73.

21] Prasetya $D$, Ma'rufi $I$ and Indrayani $R$ (2018) Determinan Stres Kerja pada Penjaga Palang Pintu Rel Kereta Api Resmi Resort 9.6 Daerah Operasi IX di Kabupaten Jember. Jurnal Kesehatan 6(No. 2): 76-82.

22] Putranto C (2013) Faktor-faktor yang Mempengaruhi Stres Kerja : Studi
Indigenous pada Guru Bersuku Jawa. Journal of Social and Industrial Psychology 2(No. 2): 12-17.

23] Riskesdas (2018) Hasil Utama Riskesdas 2018. Jakarta: Kementerian Kesehatan RI Badan Penelitian dan Pengembangan Kesehatan.

24] Shabir M (2015) Kedudukan Guru sebagai Pendidik. Auladuna 2(No. 2): 221-232.

25] Sumarna U, Sumarni $N$ and Rosidin $U$ (2018) Bahaya Kerja serta Faktor-Faktor yang Mempengaruhinya. Yogyakarta: Deepublish.

26] Suparman (2018) Identifikasi Gejala Stres pada Guru Tingkat Sekolah Dasar di Sekolah Lentera Harapan Tangerang. Jurnal Pendidikan Dompet Dhuafa 8(No. 1): 7-12.

27] Susanti R, Riswani and Bakhtiar N (2018) Kejenuhan di Kalangan Guru Bimbingan dan Konseling di SMAN Provinsi Riau. Educational Guidance and Counseling Development Journal 1(No. 2): 92-104.

28] Wahdaniyah $N$ and Miftahuddin (2018) Pengaruh Hardiness, Beban Kerja, dan Faktor Demografi terhadap Stres Kerja Guru. Tazkiya Journal of Psychology 6(No. 1): 69-83.

29] Wardhani U, Muchtar R and Farhiyani A (2020) Hubungan Stres Kerja dengan Kejenuhan (Burnout) Kerja pada Perawat di Rumah Sakit X Kota Batam. Jurnal Amanah Kesehatan 2(No. 1): 83-97.

30] Wibowo I and Maqfirotun S (2016) Peran Guru dalam Membentuk Tanggung Jawab Siswa Kelas V Sekolah Dasar. Jurnal Gentala Pendidikan Dasar 1(No. 1): 6172.

31] Yusuf A. Muri (2014) Metode Penelitian: Kuantitatif, Kualitatif, dan Penelitian Gabungan. Jakarta: Kencana.

32] Zetli S (2019) Hubungan Beban Kerja Mental terhadap Stres Kerja pada Tenaga Kependidikan di Kota Batam. Jurnal Rekayasa Sistem Industri 4(No. 2): 63-70.

33] Zulkifli, Tri S and Akbar S (2019) Hubungan Usia, Masa Kerja, dan Beban Kerja dengan Stres Kerja pada Karyawan Service Well Company PT. Elnusa Tbk. Wilayah Muara Badak. Jurnal Kesehatan Masyarakat 5(No. 1): 47-61. 